\title{
PENGARUH KAPASITAS SUMBERDAYA MANUSIA, PEMANFAATAN TEKNOLOGI INFORMASI, DAN PENGENDALIAN INTERN AKUNTANSI TERHADAP NILAI INFORMASI PELAPORAN KEUANGAN PEMERINTAH DAERAH, STUDI PADA PEMERINTAH KOTA MAGELANG
}

\author{
Hendira Rita Kartika \\ Dewi Amalia
}

\begin{abstract}
This research aims to understand the influence of the capacity of human resources, the utilization of information technology, internal control and accounting on the value of information reporting local government finance. Of respondents in this research is the head and staff the subsection accounting and finance at penatausahaan skpd magelang city of central java province. The number of respondents in this research is 65. Data collection done by means of spreading the questionnaire directly to the secretariat skpd magelang city. The technique of analysis of data using linear regression analysis double. The result of testing on each of the independent variable shows that the capacity of human resources have influence on the information the government financial reporting magelang the city. While the use of information technology and control of internal accounting have no influence on the information the government financial reporting Magelang city.

Keywords: the value of local government financial reporting information, the capacity of human resources, utilization of information technology, accounting and internal control.
\end{abstract}

\section{PENDAHULUAN}

Peristiwa yang terjadi dalam perkembangan sektor publik di Indonesia ini adalah menguatnya tuntutan transparency (keterbukaan informasi) atas lembagalembaga publik, baik pusat maupun daerah. Terkait dengan tugas untuk menegakkan akuntabilitas finansial khususnya di daerah, pemerintah daerah bertanggungjawab untuk mempublikasikan laporan keuangan kepada pemangku kepentingannya. Informasi yang diberikan dalam pelaporan keuangan harus bermanfaat bagi para pemakai, dengan mengatakan bahwa infomasi harus mempunyai nilai (Suwardjono, 2005: 169). 
Adapun kriteria dan unsur-unsur pembentuk kualitas informasi yang menjadikan informasi dalam laporan keuangan pemerintah mempunyai nilai atau manfaat terdiri dari relevan, andal, dapat dibandingkan, dan dapat dipahami. Sistem akuntansi sebagai suatu sistem informasi yang membutuhkan manusia untuk menjalankan sistem yang ada. Untuk dapat menghasilkan laporan keuangan yang berkualitas, maka kapasitas sumberdaya manusia yang melaksanakan sistem akuntansi sangatlah penting.

Penelitian mengenai sumberdaya manusia yang ada di instansi pemerintah pernah dilakukan. Penelitian Dinata (2004) menemukan bukti empiris bahwa secara garis besar sumberdaya manusia yang ada di instansi pemerintah kota Palembang belum sepenuhnya dinyatakan siap atas berlakunya Sistem Akuntansi keuangan Daerah yang berdasarkan Keputusan Menteri Dalam Negeri Nomor 29 Tahun 2002 (Dinata, 2004). Penelitian Alimbudiono dan Fidelis (2004) memberikan temuan empiris bahwa pegawai berlatar pendidikan akuntansi di sub bagian akuntansi Pemerintah Kota Palembang masih minim dan pelatihan-pelatihan untuk menjamin fungsi akuntansi berjalan dengan baik belum dilaksanakan.

Hal kedua yang mungkin mempengaruhi nilai informasi pelaporan keuangan pemerintah daerah adalah pemanfaatan teknologi informasi. Peningkatan volume transaksi yang semakin besar dan kualitas yang semakin rumit dan semakin kompleks tentu harus diikuti dengan peningkatan kemampuan pengelolaan keuangan pemerintah (Sugijanto, 2002). Kewajiban Pemanfaatan Teknologi Informasi oleh Pemerintah dan Pemerintah Daerah diatur dalam Peraturan Pemerintah Nomor 56 Tahun 2005 tentang Sistem Informasi Keuangan Daerah. Belum optimalnya pemanfaatan teknologi informasi ini mungkin juga memiliki pengaruh terhadap keterandalan pelaporan keuangan pemerintah daerah.

Hal ketiga yang mungkin mempengaruhi nilai informasi pelaporan keuangan pemerintah daerah adalah pengendalian intern akuntansi. Sistem akuntansi sebagai sistem informasi merupakan subjek terjadinya kesalahan baik yang disengaja maupun yang tidak disengaja. Oleh karena itu, sistem akuntansi memerlukan 
pengendalian intern. Pengendalian intern terdiri dari lima komponen yang saling berkaitan antara lain: lingkungan pengendalian, penaksiran risiko, aktivitas pengendalian, informasi dan komunikasi, serta pemantauan.

Penelitian tentang nilai informasi pelaporan keuangan pemerintah daerah ini pernah dilakukan oleh Indriasari (2008) yang menyatakan bahwa ada pengaruh kapasitas sumberdaya manusia, pemanfaatan teknologi, dan pengendalian inten akuntansi terhadap nilai informasi akuntansi pelaporan keuangan pemerintah daerah di Kota Palembang dan Kabupaten Ogan Ilir. Bukti penelitian ini didukung oleh hasil penelitian Risa (2008) yang mengatakan bahwa kapasitas sumberdaya manusia, pemanfaatan teknologi, dan pengendalian intern berpengaruh terhadap nilai informasi pelaporan keuangan pemerintah daerah.

Lokasi yang akan diteliti dalam penelitian ini adalah Pemerintah Kota Magelang yang merupakan kota yang letaknya strategis serta menciptakan pelayanan jasa dalam semua bidang (pendidikan, perdagangan, pariwisata, dan kesehatan). Mengingat pentingnya nilai informasi pelaporan keuangan pemerintah daerah, maka peneliti melakukan penelitian mengenai pengaruh kapasitas sumberdaya manusia, pemanfaatan teknologi informasi, dan pengendalian intern akuntansi terhadap nilai informasi pelaporan keuangan pemerintah daerah, studi pada Pemerintah Kota Magelang.

\section{TINJAUAN PUSTAKA DAN PENGEMBANGAN HIPOTESIS}

\section{Pelaporan Keuangan Pemerintah Daerah}

Standar Akuntansi Pemerintah (2008) mendefinisikan bahwa laporan keuangan pada dasarnya disusun untuk menyediakan informasi yang relevan mengenai posisi keuangan dan seluruh transaksi yang dilakukan oleh suatu entitas pelaporan selama satu perioda pelaporan. Laporan keuangan organisasi sektor publik merupakan informasi keuangan yang berfungsi memberikan dasar pertimbangan untuk pengambilan keputusan (Mardiasmo, 2002: 159). Tujuan 
pelaporan keuangan pemerintah menurut Peraturan Pemerintah Nomor 24 Tahun 2005 adalah:

1. Akuntabilitas, yaitu mempertanggungjawabkan pengelolaan sumberdaya serta pelaksanaan kebijakan yang dipercayakan kepada entitas pelaporan dalam mencapai tujuan yang telah ditetapkan secara periodik.

2. Manajemen yaitu membantu para pengguna untuk mengevaluasi pelaksanaan kegiatan suatu entitas pelaporan dalam perioda pelaporan sehingga memudahkan fungsi perencanaan, pengelolaan dan pengendalian atas seluruh aset, kewajiban, dan ekuitas pemerintah untuk kepentingan masyarakat.

3. Transparansi yaitu memberikan informasi keuangan yang terbuka dan jujur kepada masyarakat berdasarkan pertimbangan bahwa masyarakat memiliki hak untuk mengetahui secara terbuka dan menyeluruh atas pertanggungjawaban pemerintah dalam pengelolaan sumberdaya yang dipercayakan kepadanya dan ketaatannya pada peraturan perundang-undangan.

4. Keseimbangan antar generasi, yaitu membantu para pengguna dalam mengetahui kecukupan penerimaan pemerintah pada perioda pelaporan untuk membiayai seluruh pengeluaran yang dialokasikan dan apakah generasi yang akan datang diasumsikan akan ikut menanggung beban pengeluaran tersebut.

5. Evaluasi kinerja, yaitu mengevaluasi kinerja entitas pelaporan, terutama dalam penggunaan sumberdaya ekonomi yang dikelola pemerintah untuk mencapai kinerja yang direncanakan.

\section{Nilai informasi}

Manfaat dan tujuan penyajian laporan keuangan pemerintah dapat dipenuhi maka informasi yang disajikan harus merupakan informasi yang bermanfaat bagi pihak yang berkepentingan dengan informasi tersebut. Mengatakan bahwa informasi harus bermanfaat bagi para pemakai sama saja dengan mengatakan bahwa informasi harus mempunyai nilai (Suwardjono, 2005: 169-178). Kualitas yang menjadikan informasi mempunyai nilai atau manfaat mempunyai unsur-unsur 
pembentuk sebagai berikut keterpahaman (understanbility), keberpautan (relevance), nilai prediktif (prediktif value), nilai balikan (feedback value), ketepatan waktu (timeliness), dan keterandalan (reliability).

\section{Kapasitas Sumberdaya Manusia}

Kapasitas sumberdaya manusia merupakan kemampuan seseorang atau individu, suatu organisasi (kelembagaan), atau sistem untuk melaksanakan fungsifungsi atau kewenangannya untuk mencapai tujuannya secara efektif dan efisien. Menurut Tjiptoherijanto (2001) dalam Alimbudiono dan Fidelis (2004), untuk menilai kapasitas dan kualitas sumberdaya manusia dalam melaksanakan suatu fungsi, termasuk akuntansi, dapat dilihat dari level of responsibility dan kompetensi sumberdaya tersebut. Tanggung jawab dapat dilihat dalam deskripsi jabatan. Kompetensi merupakan suatu karakteristik dari seseorang yang memiliki ketrampilan (skill), pengetahuan (knownledge), kemampuan (ability) melaksanakan suatu pekerjaan (Hevesi, 2005). Keberadaan sumberdaya manusia menjadi kunci dalam pengembangan kemampuan kapasitas pemerintah daerah secara menyeluruh.

\section{Teknologi Informasi}

Teknologi informasi meliputi komputer (mainframe, mini, micro), perangkat lunak (software), database, jaringan (internet, intranet), elekronik commerce, dan jenis lainnya yang berhubungan dengan teknologi (Wilkinson et al., 2000). Pengolahan data menjadi suatu informasi dengan bantuan komputer jelas akan lebih meningkatkan nilai informasi yang dihasilkan. Penyiapan laporan lebih tepat waktu, tempat penyimpanan data lebih ringkas dengan aksesibilitas lebih tinggi ketika dibutuhkan, dan juga pemasukan data lebih banyak.

\section{Pengendalian Intern Akuntansi}

Pengendalian intern meliputi struktur organisasi, metoda, dan ukuran-ukuran yang dikoordinasikan untuk menjaga kekayaan organisai tersebut, mendorong efisiensi, dan mengecek ketelitian dan keterandalan data akuntansi. Pengendalian 
intern akuntansi yang merupakan bagian dari pengendalian intern yang berkaitan dengan tujuan pertama dan kedua, sedangkan pengendalian intern administratif berkaitan dengan tujuan ketiga dan keempat.

Unsur-unsur pokok yang diperlukan dalam menciptakan pengendalian intern akuntansi yang efektif antara lain adanya perlindungan fisik terhadap harta, pemisahan fungsi organisasi yaitu pemisahan fungsi organisasi yang saling berkaitan, adanya jejak audit yang baik, sumberdaya manusia yang optimal (Wahana Komputer, 2003). Sedangkan Mahmudi (2007) menyebutkan komponen yang terkait dengan pengendalian intern akuntansi antara lain sebagai sistem dan prosedur akuntansi, otorisasi, formulir, dokumen, dan catatan, serta pemisahan tugas.

\section{Pengaruh Kapasitas Sumberdaya Manusia terhadap Nilai Informasi Pelaporan Keuangan Pemerintah Daerah}

Meskipun sistem akuntansi sudah dijalankan dengan baik, tetapi sumberdaya manusia tidak memiliki kapasitas untuk melaksanakannya, maka akan menimbulkan hambatan dalam pelaksanaan fungsi akuntansi yang ada dan akhirnya informasi akuntansi tersebut kualitasnya menjadi buruk. Informasi yang dihasilkan menjadi informasi yang kurang atau tidak memiliki nilai. Kapasitas sumberdaya manusia yang memadai dari segi kualitas dan kuantitatif akan meningkatkan kandungan nilai informasi dalam pelaporan keuangan pemerintah daerah.

Indriasari (2008) membuktikan bahwa kapasitas sumberdaya manusia berpengaruh terhadap nilai informasi pelaporan keuangan pemerintah daerah di Kota Palembang dan Kabupaten Ogan Ilir Provinsi Sumatra Selatan. Bukti penelitian ini didukung oleh hasil penelitian Risa (2008) serta Winidyaningrum dan Rahmawati (2010) yang menyatakan bahwa kapasitas sumberdaya manusia berpengaruh nilai informasi pelaporan keuangan pemerintah daerah. Sehingga dapat dirumuskan hipotesis sebagai berikut. 
$\mathrm{H}_{1}$ : Kapasitas sumberdaya manusia berpengaruh terhadap nilai informasi pelaporan keuangan pemerintah daerah.

\section{Pengaruh Pemanfaatan Teknologi Informasi terhadap Nilai Informasi Pelaporan Keuangan Pemerintah Daerah}

Melalui Peraturan Pemerintah Nomor 56 Tahun 2005 tentang Sistem Informasi Keuangan Daerah (SIKD), pemerintah telah mengamanatkan pelaksanaan SIKD baik pusat maupun daerah dalam rangka menunjang perumusan kebijakan fiskal secara nasional serta meningkatkan transparansi dan akuntabilitas dalam pelaksanaan desentralisasi. Penyelenggaran SIKD diharapkan dapat menghasilkan data yang berkualitas yaitu relevan, akurat, tepat waktu, dan dapat dipertanggungjawabkan. Teknologi informasi dapat berpengaruh terhadap sistem akuntansi, perubahan proses bisnis dan bukti yang tersedia untuk mendukung transaksi bisnis. Pemanfaatan teknologi informasi untuk menyusun dan menyajikan laporan keuangan akan meningkatkan nilai informasi pelaporan keuangan pemerintah daerah.

Risa (2008) membuktikan bahwa penggunaan software akuntansi oleh pemerintah daerah dapat berpengaruh terhadap relevansi dan reliabilitas informasi dalam laporan keuangan pemerintah daerah. Sementara itu, Indriasari (2008) serta Winidyaningrum dan Rahmawati (2010) memperoleh bukti penelitian bahwa pemanfaatan teknologi informasi dapat berpengaruh terhadap nilai informasi pelaporan keuangan pemerintah daerah yang dinyatakan dengan keterandalan dan ketepatan waktu penyampaian laporan keuangan pemerintah daerah. Sehingga dapat dirumuskan hipotesis sebagai berikut:

$\mathrm{H}_{2}$ : Pemanfaatan Teknologi Informasi berpengaruh terhadap nilai informasi pelaporan keuangan Pemerintah Daerah.

Pengaruh Pengendalian Intern Akuntansi terhadap Nilai Informasi Pelaporan Keuangan Pemerintah Daerah 
Penyimpangan dan kebocoran yang masih ditemukan dalam laporan keuangan menunjukkan bahwa laporan keuangan tersebut belum memenuhi nilai informasi yaitu keterandalan. Ketergantungan terhadap sistem dan pengendalian teknologi informasi menjadi hal penting, karena sedikitnya adanya bukti kertas asli untuk dicek dengan transaksi. Dengan adanya pengendalian intern yang efektif akan meningkatkan nilai informasi pelaporan keuangan Pemerintah Daerah.

Indriasari (2008) serta Winidyaningrum dan Rahmawati (2010) membuktikan secara empiris bahwa pengendalian intern akuntansi pemerintah daerah berpengaruh terhadap nilai informasi pelaporan keuangan pemerintah daerahs. Berdasarkan uraian tersebut dan temuan empiris tersebut, penulis mengajukan hipotesis:

$\mathrm{H}_{3}$ : Pengendalian intern akuntansi berpengaruh terhadap nilai informasi pelaporan keuangan pemerintah daerah.

\section{Model Penelitian}

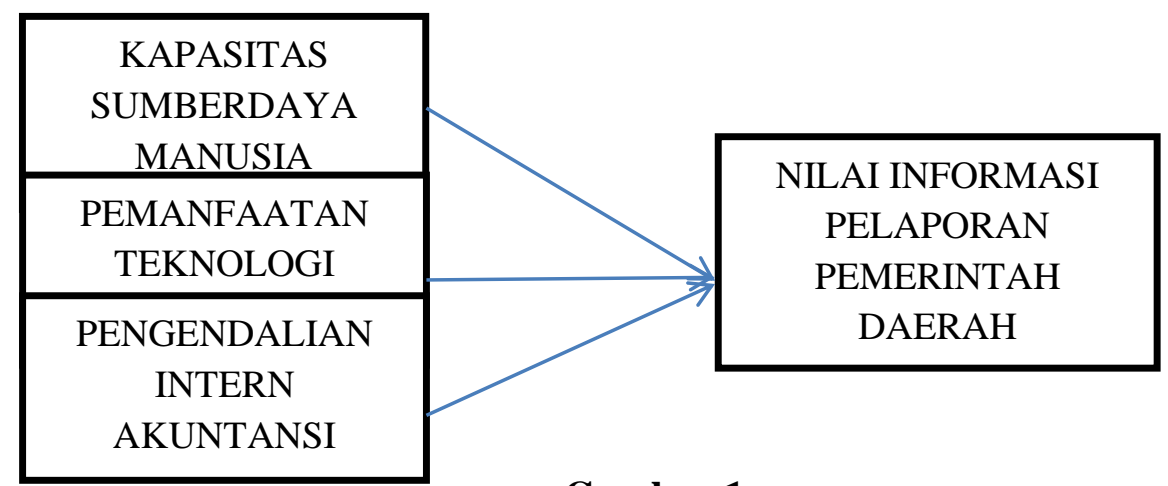

\section{Gambar 1 \\ Model Penelitian}

\section{METODA PENELITIAN}

\section{Populasi dan Sampel}

Populasi dalam penelitian ini adalah pegawai bagian akuntansi/penatausahaan keuangan yang bekerja di SKPD Kota Magelang. Sampel dalam penelitian ini adalah kepala dan staf sub bagian akuntansi/penatausahaan keuangan di SKPD Kota Magelang. Teknik yang digunakan dalam penyampelan atas responden 
dilakukan secara purposive sampling, karena informasi yang akan diambil berasal dari sumber yang sengaja dipilih berdasarkan kriteria yang telah ditetapkan peneliti (Indriantoro dan Supomo, 1999: 131).

Data yang digunakan dalam penelitian ini adalah data primer. Pengumpulan data akan dilakukan melalui kuesioner yang diantar dan diambil sendiri oleh peneliti terhadap bagian akuntansi/penatausahaan keuangan pada SKPD. SKPD ini meliputi dinas, badan, kantor, dan bagian. Lokasi penelitian terbatas di Kota Magelang Provinsi Jawa Tengah.

\section{Definisi Operasional dan Pengukuran Variabel}

\section{Nilai Informasi Pelaporan Keuangan Pemerintah Daerah}

Keterandalan merupakan kemampuan informasi untuk memberikan keyakinan bahwa informasi tersebut benar atau valid (Peraturan Pemerintah Nomor 24 Tahun 2005). Variabel nilai informasi pelaporan keuangan pemerintah daerah menggunakan 5 skala Likert. Skor (1) menunjukkan rendahnya keterandalan pelaporan keuangan pemerintah daerah dan skor 5 menunjukkan tingginya keterandalan pelaporan keuangan pemerintah daerah (skor 1: sangat tidak setuju, skor 2: tidak setuju, skor 3: netral, skor 4: setuju, skor 5: sangat setuju).

\section{Kapasitas Sumberdaya Manusia}

Kapasitas sumberdaya manusia adalah kemampuan baik dalam tingkatan individu, organisasi/kelembagaan maupun sistem untuk melaksanakan fungsifungsi atau kewenangannya untuk mencapai tujuannya secara efektif dan efisien (Laporan akhir studi GTZ \& USAID/CLEAN UPBAN (2001)). Variabel kapasitas sumberdaya manusia menggunakan 5 skala Likert. Skor (1) menunjukkan rendahnya kapasitas sumberdaya manusia dan skor 5 menunjukkan tingginya kapasitas sumberdaya manusia.

\section{Pemanfaatan Teknologi Informasi}


Menurut Jurnali dan Supomo (2001) pemanfaatan teknologi informasi merupakan tingkat integrasi teknologi informasi pada pelaksanaan tugas-tugas akuntansi. Variabel pemanfaatan teknologi informasi menggunakan 5 skala Liker., Skor (1) menunjukkan rendahnya pemanfaatan teknologi informasi dan skor 5 menunjukkan tingginya pemanfaatan teknologi informasi.

\section{Pengendalian Intern Akuntansi}

Pengendalian intern meliputi srtuktur organisasi, metoda, dan ukuran-ukuran yang dikoordinasikan untuk menjaga kekayaan organisasi tersebut, mendorong efisiensi, dan mengecek ketelitian dan keterandalan data akuntansi. Variabel pengendalian intern akuntansi menggunakan 5 skala Likert. Skor (1) menunjukkan rendahnya pengendalian intern akuntansi dan skor 5 menunjukkan tingginya pengendalian intern akuntansi.

\section{Teknik Analisis Data}

\section{Uji Kualitas Data}

Uji Validitas digunakan untuk mengukur sah atau valid tidaknya kuesioner. Suatu kuesioner dikatakan valid jika pernyataan pada kuesioner mampu untuk mengungkapkan sesuatu yang diukur oleh kuesioner tersebut (Ghozali, 2006: 49). Uji validitas dalam penelitian ini yaitu dengan melakukan korelasi bivariate antara masing-masing skor indikator dengan total skor konstruk.

Uji reliabilitas dilakukan dengan cara menghitung nilai Cronbach alpha dari masing-masing instrumen dalam suatu variabel. Nilai cut off untuk menentukan reliabilitas adalah nilai cronbach alpha lebih dari 0,60 (Nunnally, 1978).

\section{Regresi Linear Berganda}

Analisis regresi berganda dilakukan untuk mengetahui pengaruh tiap variabel independen terhadap variabel dependen (Ghozali, 2006: 85). Persamaan regresi untuk menguji hipotesis-hipotesis yang diajukan dinyatakan dengan model sebagai berikut: 


\section{$\mathrm{NIPK}=\mathbf{a}+\mathrm{b}_{1} \mathrm{KSDM}+\mathrm{b}_{2} \mathrm{PTI}+\mathrm{b}_{3} \mathrm{PIA}+\mathrm{e}$}

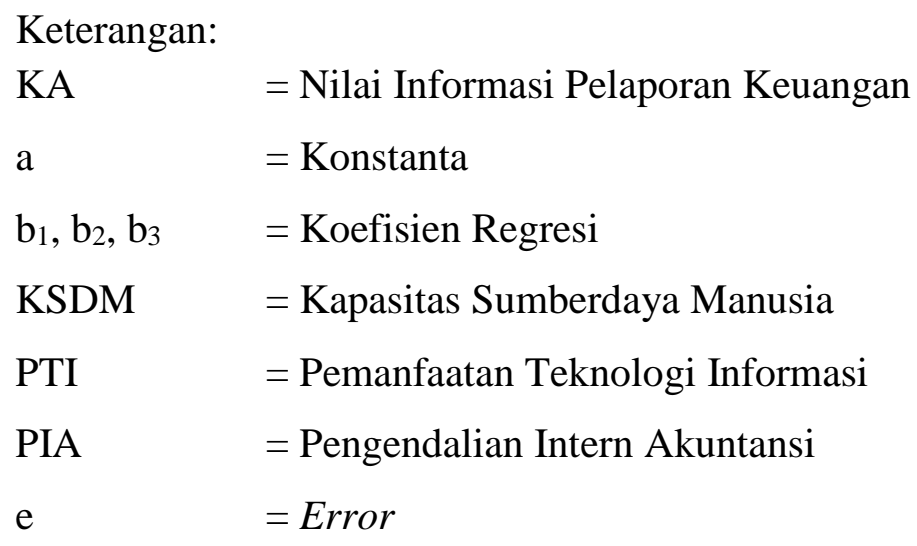

\section{Uji regresi linear berganda terdiri dari:}

\section{Uji Asumsi Klasik}

Penelitian ini menggunakan 4 jenis uji asumsi klasik yang mendasari model analisis regresi, yaitu: pengujian multikolinieritas dengan menggunakan nilai tolerance dan varian inflasion faktor (VIF), pengujian heteroskedastisitas dengan menggunakan uji Glejser, pengujian normalitas dengan menggunakan Kolmogorov Smirnov, serta pengujian autokorelasi dengan menggunakan Durbin-Watson test.

\section{Uji Hipotesis}

\section{Uji Koefisien Determinasi $\left(\mathbf{R}^{2}\right)$}

Koefisien determinasi $\left(\mathrm{R}^{2}\right)$ pada intinya mengukur kemampuan model dalam menerangkan variasi variabel dependen. Akan tetapi, nilai koefisien determinasi $\left(\mathrm{R}^{2}\right)$ memiliki kelemahan mendasar yaitu bias terhadap jumlah variabel independen yang dimasukkan ke dalam. Jadi, dalam penelitian ini menggunakan nilai adjusted $\mathrm{R}^{2}$ pada saat mengevaluasi model yang terbaik (Ghozali, 2006: 87).

\section{Uji F}

Uji stastistik F menunjukkan semua variabel independen secara bersamasama atau paling tidak ada satu variabel independen yang berpengaruh terhadap 
variabel dependen terikat dalam suatu model (Ghozali, 2006: 84). Dasar pengambilan keputusan pada uji $\mathrm{F}$ ini adalah dengan melihat nilai probabilitas signifikansi 5\%. Jika nilai probabilitas < tingkat kepercayaan $(\alpha)$, maka terdapat pengaruh variabel independen terhadap variabel dependen, dan sebaliknya (Ghozali, 2006: 88-91).

\section{Uji t}

Uji statistik t pada dasarnya menunjukkan pengaruh variabel independen secara individual dalam menerangkan variasi variabel dependen. Untuk menggunakan koefisien variabel independen dapat menggunakan nilai probabilitas signifikansi. Dasar pengambilan keputusan pada uji $t$ ini adalah dengan melihat nilai probabilitas signifikansi. Jika nilai probabilitas signifikansi < tingkat kepercayaan $(\alpha)$, maka variabel independen secara individu mempengaruhi variabel dependen. Hal ini berarti menerima $\mathrm{H}_{\mathrm{a}}$ dan menolak $\mathrm{H}_{\mathrm{o}}$, dan sebaliknya.

\section{HASIL DAN PEMBAHASAN}

\section{Penyebaran Kuesioner di Skpd Kota Magelang}

Tabel 1

Demografi Responden

\begin{tabular}{|c|c|c|c|}
\hline \multicolumn{2}{|c|}{ Keterangan } & Frekuensi & Persentase \\
\hline \multirow{2}{*}{ Responden bagian keuangan } & $\begin{array}{c}\text { SKPD di Kota } \\
\text { Magelang }\end{array}$ & 65 & $100 \%$ \\
\hline \multirow{2}{*}{ Jenis kelamin } & Laki-laki & 27 & $41,50 \%$ \\
\cline { 2 - 4 } & Perempuan & 38 & $58,50 \%$ \\
\hline Usia & 25-35 Tahun & 40 & $62 \%$ \\
\cline { 2 - 4 } & 36-50 Tahun & 25 & $38 \%$ \\
\hline
\end{tabular}

Sumber: Data primer, diolah (2013) 


\section{Analisis Deskriptif}

\section{Tabel 2}

Statistik Deskriptif Variabel Penelitian

\begin{tabular}{|c|c|c|c|c|c|}
\hline & N & Minimum & Maksimum & Rata-rata & Deviasi Standar \\
\hline DM & 65 & 3,7 & 5 & 46 & 0,4 \\
PTI & 65 & 3 & 5 & 42 & 0,65 \\
PIA & 65 & 1 & 5 & 37 & 0,83 \\
NIPK & 65 & 3 & 5 & 41 & 0,63 \\
Valid N (listwise) & 65 & & & & \\
\hline
\end{tabular}

Sumber: Data primer, diolah (2013).

Berdasar hasil pengukuran variabel kapasitas sumberdaya manusia pada tabel 2 skor jawaban responden berkisar antara 3,7 hingga 5,0 dengan rata-rata 46. Hal ini menunjukkan bahwa terdapat responden dalam penelitian ini yang pengetahuan tentang kapasitas sumberdaya manusia yang tergolong baik. Deviasi standar variabel ini sebesar 0,4 menunjukkan variasi kapasitas sumberdaya manusia.

Berdasar hasil pengukuran variabel pemanfaatan teknologi informasi pada tabel 2 skor jawaban responden berkisar antara 3,0 hingga 5,0 dengan rata-rata 42 . Hal ini menunjukkan bahwa terdapat responden dalam penelitian ini yang mempunyai pemanfaatan teknologi informasi yang tergolong baik. Deviasi standar variabel ini sebesar 0,65 menunjukkan variasi pemanfaatan teknologi informasi.

Berdasar hasil variabel pengendalian intern akuntansi pada tabel 2 skor jawaban responden berkisar antara 1,0 hingga 5,0 dengan rata-rata 37. Hal ini menunjukkan bahwa terdapat responden dalam penelitian ini yang mempunyai pengendalian intern akuntansi yang tergolong baik. Deviasi standar variabel ini sebesar 0,83 menunjukkan variasi pengendalian intern akuntansi.

Berdasar hasil variabel nilai informasi pelaporan keuangan pemerintah daerah pada tabel 2 skor jawaban responden berkisar 3,0 hingga 5,0 dengan ratarata 41. Hal ini menunjukkan bahwa terdapat responden yang mempunyai nilai informasi pelaporan keuangan pemerintah daerah yang tergolong baik. Deviasi 
standar variabel ini sebesar 0,63 menunjukkan variasi nilai informasi pelaporan keuangan pemerintah daerah.

\section{Uji Kualitas Data}

Berdasarkan hasil uji validitas dengan menggunakan korelasi bivariate yang telah dilakukan tehadap kuesioner, maka dapat disimpulkan bahwa semua indikator valid pada variabel kapasitas sumberdaya manusia, pemanfaatan teknologi informasi, pengendalian intern akuntansi, dan nilai informasi pelaporan keuangan pemerintah daerah valid.

Berdasarkan hasil uji reliabilitas terhadap masing-masing kuesioner pengukur variabel penelitian menunjukkan kuesioner yang digunakan dalam penelitian ini secara statistika layak digunakan sebagai alat pengumpul data karena telah memenuhi validitas dan reliabilitas yang disyaratkan.

\section{Analisis Regresi Berganda}

\section{Uji Asumsi Klasik}

\section{a. Uji Normalitas}

Hasil uji normalitas pada tabel 3 menunjukkan bahwa besarnya nilai asymp. sig. (2-tailed) adalah 0,710 lebih besar dari nilai alpha $(0,05)$ dapat disimpulkan bahwa data residual terdistribusi secara normal. Dengan demikian tidak ada variabel pengganggu yang memiliki distribusi tidak normal.

Tabel 3

Hasil Uji Normalitas

\begin{tabular}{|l|c|c|}
\hline \multicolumn{1}{|c|}{ Keterangan } & Unstandardized Residual & \multirow{2}{*}{ Alpha } \\
\hline $\mathrm{N}$ & 65 & \multirow{2}{*}{0,05} \\
\hline asymp. sig. (2-tailed) & 0,710 & \\
\hline
\end{tabular}

Sumber: Data primer, diolah (2013).

\section{b. Uji Multikolinieritas}

Hasil pengujian multikolinieritas pada tabel 4 menyatakan bahwa nilai VIF dan tolerance pada masing-masing variabel independen menunjukkan angka lebih 
kecil dari 10 dan lebih besar dari 0,10, Berdasar hasil tersebut, maka diketahui bahwa tidak ada multikolinieritas.

Tabel 4

Hasil Uji Multikolinieritas

\begin{tabular}{|l|c|c|c|}
\hline \multicolumn{1}{|c|}{ Variabel } & Tolerance & VIF & Keterangan \\
\hline $\begin{array}{l}\text { Kapasitas Sumberdaya } \\
\text { Manusia }\end{array}$ & 0,970 & 1,031 & $\begin{array}{c}\text { Tidak terdapat } \\
\text { Multikolinieritas }\end{array}$ \\
\hline $\begin{array}{l}\text { Pemanfaatan Teknologi } \\
\text { Informasi }\end{array}$ & 0,971 & 1,030 & $\begin{array}{c}\text { Tidak terdapat } \\
\text { Multikolinieritas }\end{array}$ \\
\hline $\begin{array}{l}\text { Pengendalian Intern } \\
\text { Akuntansi }\end{array}$ & 0,990 & 1,010 & $\begin{array}{c}\text { Tidak terdapat } \\
\text { Multikolinieritas }\end{array}$ \\
\hline
\end{tabular}

Sumber: Data primer, diolah (2013).

\section{c. Uji Heteroskedastisitas}

Hasil uji Glejser pada tabel 5 menunjukkan nilai signifikansi variabel independen di atas tingkat kepercayaan 0,05. Dengan demikian, diketahui bahwa model regresi tidak mengandung adanya heteroskedastisitas

Tabel 5

Hasil Uji Heteroskedastisitas

\begin{tabular}{|c|c|c|}
\hline Variabel & Sig & Alpha \\
\hline Kapasitas sumberdaya manusia & 0,224 & 0,05 \\
\hline Pemanfaatan teknologi informasi & 0,713 & 0,05 \\
\hline Pengendalian intern akuntansi & 0,594 & 0,05 \\
\hline
\end{tabular}

Sumber: Data primer, diolah (2013).

\section{d. Uji Autokorelasi}

Berdasar hasil analisis regresi yang telah dilakukan pada tabel 6 Diperoleh nilai DW= 2,006 lebih besar dari dU $(1,696)$ dan kurang dari $4-\mathrm{du}(2,304)$. Oleh karena itu, diketahui bahwa tidak terdapat autokorelasi positif maupun negatif pada model regresi. 
Tabel 6

Hasil Uji Autokorelasi

\begin{tabular}{|c|c|c|}
\hline Model & Durbin-Watson & dU \\
\hline 1 & 2,006 & 1,696 \\
\hline
\end{tabular}

Sumber: Data primer, diolah (2013).

\section{Uji Hipotesis}

\section{a. Uji Koefisien Determinasi}

Berdasar tabel 7, besarnya nilai adjusted $R$ square sebesar 0,145 Nilai ini menerangkan besarnya peran atau kontribusi variabel independen yang mampu menjelaskan variabel dependen sebesar $14,5 \%$. Sedangkan sisanya sebesar $85,5 \%$ dijelaskan oleh faktor-faktor lain di luar model yang dianalisis.

Tabel 7

Hasil Uji Koefisien Determinan

\begin{tabular}{|l|l|l|l|l|}
\hline Model & $\mathbf{R}$ & $\boldsymbol{R}$ Square & Adjusted R square & Std. Eror of the Estimate \\
\hline 1 & 0,430 & 0,185 & 0,145 & 302,525 \\
\hline
\end{tabular}

Sumber: Data primer, diolah(2013).

\section{b. Uji F}

Berdasar tabel 8 terlihat nilai $\mathrm{F}$ dalam regresi menunjukkan pengaruh variabel independen terhadap variabel dependen. Regresi total memiliki F hitung sebesar 4,616 dengan signifikansi 0,000 yang menunjukkan bahwa nilai signifikansi tersebut $<0,05$ berarti minimal terdapat salah satu variabel independen yang berpengaruh terhadap variabel dependen.

Tabel 8

Hasil Uji Statistik F

\begin{tabular}{|l|l|l|}
\hline Model & F & Signifikansi \\
\hline
\end{tabular}




\begin{tabular}{|l|l|l|l|}
\hline 1 & Regresi total & 4,616 & 0,000 \\
\hline
\end{tabular}

Sumber: Data primer, diolah (2013).

c. Uji t

Tabel 9

Hasil Uji Statistik t

\begin{tabular}{|l|l|l|l|}
\hline \multicolumn{1}{|c|}{ Variabel } & Sig. & Alpha & Keterangan \\
\hline Kapasitas sumberdaya manusia & 0,001 & 0,05 & $\mathrm{H}_{1}$ diterima \\
\hline Pemanfaatan teknologi informasi & 0,244 & 0,05 & $\mathrm{H}_{2}$ ditolak \\
\hline Pengendalian intern akuntansi & 0,298 & 0,05 & $\mathrm{H}_{3}$ ditolak \\
\hline
\end{tabular}

Sumber: Data primer, diolah (2013)

Hasil analisis regresi berganda terhadap hipotesis pertama dapat dilihat bahwa kapasitas sumberdaya manusia berpengaruh terhadap nilai informasi pelaporan keuangan pemerintah daerah dengan melihat nilai signifikansinya yaitu 0,001 yang berarti kurang dari taraf signifikansi $0,05(0,001<0,05)$. Sehingga hipotesis pertama penelitian ini dapat diterima. Hasil penelitian ini mendukung penelitian yang dilakukan oleh Indriasari (2008) yang menyatakan bahwa adanya pengaruh kapasitas sumberdaya manusia terhadap nilai informasi pelaporan keuangan pemerintah daerah. Kapasitas sumberdaya manusia yang dimiliki seseorang akan memberikan konstribusi yang lebih baik apabila didukung pendidikan dan pengalaman yang memadai untuk bidang tugasnya. Hasil penelitian ini mendukung penelitian yang dilakukan oleh Indriasari (2008) yang menyatakan bahwa adanya pengaruh kapasitas sumberdaya manusia terhadap nilai informasi pelaporan keuangan pemerintah daerah.

Hasil analisis regresi terhadap hipotesis kedua diketahui bahwa pemanfaatan teknologi informasi tidak berpengaruh terhadap nilai informasi pelaporan keuangan pemerintah daerah Kota Magelang, karena memiliki nilai signifikansi 0,244 yang berarti lebih besar dari taraf signifikansi 0,05 (0,244>0,05). Dengan demikian, hipotesis kedua yang diajukan oleh peneliti ditolak. Hasil penelitian ini tidak 
konsisten dengan penelitian yang dilakukan oleh Risa (2008) yang menyatakan bahwa pemanfaatan teknologi informasi berpengaruh terhadap nilai informasi pelaporan keuangan pemerintah daerah. Hasil ini menunjukkan bahwa pemerintah daerah Kota Magelang belum secara optimal memanfaatkan teknologi informasi dalam pelaporan keuangan.

Hasil dari analisis regresi terhadap hipotesis yang ketiga terlihat bahwa pengendalian intern akuntansi tidak berpengaruh terhadap nilai informasi pelaporan keuangan pemerintah daerah Kota Magelang. Hal ini ditunjukkan dengan nilai signifikansinya yaitu 0,298 yang berarti lebih besar dari taraf signifikansi 0,05 $(0,298>0,05)$. Dengan demikian, hipotesis ketiga yang diajukan oleh peneliti ditolak. Hasil penelitian ini tidak konsisten dengan penelitian yang dilakukan oleh Winidyaningrum dan Rahmawati (2010) yang menyatakan bahwa pengendalian intern akuntansi berpengaruh terhadap nilai informasi pelaporan keuangan pemerintah daerah. Hal ini berarti bahwa pemerintah daerah Kota Magelang belum optimal dalam melakukan pengendalian intern akuntansi dalam pelaporan keuangannya.

\section{SIMPULAN, KETERBATASAN, DAN DARAN}

Berdasar analisis data yang telah diuraikan, maka terdapat beberapa simpulan yang dapat diambil dari hasil penelitian ini:

1. Kapasitas sumberdaya manusia berpengaruh terhadap nilai informasi pelaporan keuangan pemerintah daerah Kota Magelang.

2. Pemanfaatan teknologi informasi tidak berpengaruh nilai informasi pelaporan keuangan pemerintah daerah Kota Magelang.

3. Pengendalian intern akuntansi tidak berpengaruh terhadap nilai informasi pelaporan keuangan pemerintah daerah Kota Magelang.

Penelitian ini memiliki keterbatasan-keterbatasan yang bisa dijadikan pertimbangan untuk penelitian berikutnya agar penelitiannya lebih baik lagi. Adapun keterbatasannya adalah sebagai berikut: 
1. Saat pengumpulan data yang menyebarkan adalah Sekretariat Kantor Pemerintah Daerah Kota Magelang, sehingga peneliti tidak bertemu langsung dengan responden.

2. Hasil uji determinasi menunjukkan bahwa variabel independen kapasitas sumberdaya manusia, pemanfaatan teknologi informasi, dan pengendalian intern akuntansi sangat terbatas dalam menjelaskan variasi variabel dependen nilai informasi pelaporan keuangan pemerintah daerah, yaitu sebesar 14,5\%.

3. Penelitian ini menggunakan sampel yang kecil sehingga besar kemungkinan tidak mampu merepresentasikan populasi yang baik. Kecilnya ukuran sampel merupakan salah satu kelemahan penelitian ini.

Berdasar hasil analisis pembahasan serta simpulan dan keterbatasan dalam penelitian ini, adapun saran-saran yang dapat diberikan melalui hasil penelitian ini agar mendapatan hasil yang lebih baik, yaitu:

1. Sebaiknya peneliti selanjutnya menambahkan metoda wawancara kepada responden agar responden mengetahui jelas maksud dari kuesioner yang disebar.

2. Penelitian selanjutnya sebaiknya menambah variabel lain, seperti variabel kompetensi, dan variabel kinerja aparat sebagai variabel moderating.

3. Untuk meningkatkan hasil representasi responden, penelitian selanjutnya dapat menambah responden dari berbagai pihak.

\section{DAFTAR PUSTAKA}

Alimbudiono, Ria Sandra \& Fidelis Arastyo Andono. 2004. "Kesiapan Sumber Daya Manusia Sub Bagian Akuntansi Pemerintah Daerah "XYZ" dan Kaitannya dengan Pertanggungjawaban Keuangan Daerah kepada Masyarakat: Renungan Bagi Akuntan Pendidik". Jurnal Akuntansi dan Keuangan Sektor Publik. Vol. 05 No. 02. Hal. 18-30.

Badan Pemeriksa Keuangan RI. 2006. Konsep Standar Pemeriksaan Keuangan Negara.

Bastian, Indra. 2006. Akuntansi Sektor Publik: Suatu Pengantar. Jakarta: Erlangga. 
Dinata, Anton Mulhar. 2004. Tinjauan atas Kesiapan SDM pada Instansi Pemerintah Kota Palembang dalam Penerapan Akuntansi Daerah Menuju Terciptanya Good Governance di Era Otonomi Daerah. Skripsi. Indralaya: Universitas Sriwijaya.

Forum Dosen Akuntansi Sektor Publik. 2006. Standar Akuntansi Pemerintahan: Telaah Kritis PP Nomor 24 Tahun 2004. Yogyakarta: BPFE UGM.

Ghozali, Imam. 2006. Aplikasi Analisis Multivariate dengan Program SPSS. Edisi 3. Semarang: Penerbit Universitas Diponegoro.

Governmental Accounting Standards Boards (GASB). 1999. Concepts Statement No. 1: Objectives of Financial Reporting in Governmental Accounting Standards Boards Series Statement No. 34: Basic Financial Statement and Management Discussion and Analysis for State and Local Government. Norwalk.

Hevesi, G. Alan. 2005. Standards for Internal Control in New York State Government. www.osc.state.ny.us (30 Oktober 2012).

Indriasari, Desi. 2008. Pengaruh Kapasitas Sumberdaya Manusia, Pemanfaatan Teknologi, dan Pengendalian Intern Akuntansi terhadap Nilai Informasi Pelaporan Keuangan Pemerintah Daerah pada Pemerintah Kota Palembang dan Kabupaten Organ Ilir. Tesis. Yogyakarta: Universitas Gadjah Mada.

Inspektorat Jenderal Departemen Keuangan RI. 2005. Kelemahan Desain dan Pelaksanaan Sistem Pengendalian Internal. www.itjen.depkeu.go.id. (30 Oktober 2012).

Inspektorat Jenderal Departemen Keuangan RI. 2006. "Peran Inspektorat Jenderal Departemen Keuangan Terkait dengan Laporan Keuangan Pemerintah Pusat (LKPP)". www.itjen.depkeu.go.id. (30 Oktober 2012).

Imelda. 2005. Pengaruh Penerapan Sistem Informasi Akuntansi Keuangan Daerah (SIAKD) terhadap Pengelolaan Keuangan Daerah pada Pemerintah Provinsi Sumatera Selatan. Skripsi. Indralaya: Universitas Sriwijaya.

Jurnali, Teddy \& Bambang Supomo. 2002. "Pengaruh Faktor Kesesuaian Tugas- 
Teknologi dan Pemanfaatan TI terhadap Kinerja Akuntan Publik". Jurnal Riset Akuntansi Indonesia. Vol. 5 No. 2 Hal. 214-228.

Mardiasmo. 2006. "Perwujudan Transparansi dan Akuntabilitas Publik Melalui Akuntansi Sektor Publik: Suatu Sarana Good Governance”. Jurnal Akuntansi Pemerintah, Vol. 2 No. 1, Hal. 1-17.

Mahmudi. 2007. Analisis Laporan Keuangan Daerah: Panduan Bagi Eksekutif, DPRD, dan Masyarakat dalam Pengambilan Keputusan Ekonomi, Sosial, dan Politik. Yogyakarta: UPP STIM YKPN.

Republik Indonesia, Undang-Undang Nomor 17 Tahun 2003 tentang Keuangan Negara.

Republik Indonesia, Peraturan Pemerintah Nomor 24 Tahun 2005 tentang Standar Akuntansi Pemerintahan.

Republik Indonesia, Peraturan Pemerintah Nomor 56 Tahun 2005 tentang Sistem Informasi Keuangan Daerah.

Republik Indonesia, Peraturan Menteri Dalam Negeri Nomor 13 Tahun 2006 tentang Pedoman Pengelolaan Keuangan Daerah.

Rifaldi, Angga Galih. 2011. "Pengaruh Partisipasi Anggaran terhadap Kinerja Manajerial melalui Komitmen Organisasi dan Persepsi Inovasi sebagai Variabel Intervening Studi pada Pemerintah Kabupaten Bantul”. Skripsi. Yogyakarta: Universitas Ahmad Dahlan.

Risa. 2008. Sistem Pengendalian Internal Pemerintah Daerah, Penggunaan Software Akuntansi dan Nilai Laporan Keuangan Pemerintah. Skripsi. Surakarta: UNS.

Sugijanto. 2002. Peranan Sistem Akuntansi Pemerintah Pusat dalam Meningkatkan Akuntabilitas Keuangan dan Implikasi UU Nomor 22/25 Tahun 1999. Lintasan Ekonomi. Volume XIX Nomor 1.Hal. 50-66.

Suwardjono. 2005. Teori Akuntansi: Perekayasaan Pelaporan Keuangan. Edisi Ketiga. Yogyakarta:BPFE UGM. 
Tim GTZ-USAID/CLEAN Urban. Januari 2001. Pengembangan Kapasitas bagi Pemerintahan Daerah, Suatu Kerangka Kerja bagi Pemerintah dan Dukungan Donor. Laporan Akhir: Studi Pengkajian Kebutuhan Pengembangan Kapasitas bagi Pemerintah Daerah dan DPRD. www.gtzsfdm.or.id. (30 Oktober 2012).

Tim GTZ-Support for Decentralization Measures/P4D. Mei, 2005. Pengembangan Kapasitas Pemerintahan Daerah Kabupaten Kutai Kartanegara. Jilid II: Sumberdaya Manusia Aparatur dan Kelembagaan Pemerintah.

Wahana Komputer. 2003. Panduan Aplikatif Sistem Akuntansi Online Berbasis Komputer. Yogyakarta: ANDI.

Wilkinson, W. Joseph, Michael J. Cerullo, Vasant Raval, \& Bernard Wong-OnWing. 2000. Accounting Information Systems: Essential Concepts and Applications. Fourth Edition. John Wiley and Sons.

Winidyaningrum, C, dan Rahmawati. 2010. Pengaruh Sumberdaya Manusia dan Pemanfaatan Teknologi Informasi terhadap Keterandalan dan Ketepatwaktuan Pelaporan Keuangan Pemerintah Daerah dengan Variabel Intervening Pengendalian Intern Akuntansi. Simposium Nasional Akuntansi XIII, Purwokerto, 13-15 Oktober. 